\title{
The regions in Bulgaria and the green economy - novelty or serious experience?
}

\author{
Stanka Delcheva ${ }^{{ }^{*}}$ \\ ${ }^{1}$ Public Administration Department, Faculty of Philosophy, Sofia University, Bulgaria
}

\begin{abstract}
The report presents the regional development policy in Bulgaria after 2007 with focus of the stated and implemented support for application of a green economy transition's instruments. The green economy is defined by relevant economic sectors and themes that add value to quality of life, reducing carbon emissions and creating jobs. Objective: to review the applying of instruments for transition to a green economy in the regions as part of regional development policy and promotion of the regions' competitiveness. Methods: Descriptive analysis and review of documents were used; review of planning documents at regional and municipal level and analysis of the type of applied instruments for the transition to a green economy; comparative evaluation of the already applied instruments with the forecasts for the new programming period 2021-2027. Results: The applied in the period 2007 - 2020 instruments for supporting the transition to a green economy and their connection with the development of the regions in Bulgaria are traced. The results correlation of the already applied instruments with the approach envisaged in the programming period after 2021 has been assessed. Elements of the connection between transition readiness and the regions' competitiveness are considered. Conclusions: Conclusions are drawn about the Bulgarian regions experience and capacities gained to exploit the potential and opportunities to increase competitiveness and well-being.
\end{abstract}

\section{Introduction}

Topics related to greening the economy and committing to achieving certain targets for carbon neutral economies in EU Member States are becoming key in the period after 2021. The adoption of the Green Deal and the 2050 target for carbon neutrality economy in the EU, predetermine a serious rethinking of policies and measures in a number of sectors of the economy, and especially in the most affected areas with regard to energy. At the same time, however, research pays relatively little attention to the forms in which sustainability and the green economy should take as part of the economies of the future [1].

The report presents the regional development policy in Bulgaria after 2007 with focus of the stated and implemented support for application of a green economy transition's instruments. The aim is to review the applying of instruments for transition to a green

* Corresponding author: stdelcheva@gmail.com 
economy in the regions as part of regional development policy and promotion of the regions' competitiveness.

Descriptive analysis and review of documents were used as well as review of planning documents at regional and municipal level and analysis of the type of applied instruments for the transition to a green economy; comparative evaluation of the already applied instruments with the forecasts for the new programming period 2021-2027.

\section{Green economy, circular economy, low carbon economy - definitions and connections}

The definition of the green economy is evolving in a variety of discourses. The 'green economy' has become the focus of international development since the 2008 financial crisis, as a result of the search for a restart of economies in a way that provides greater sustainability. One of the most adopted definitions is the one introduced by UNEP in 2011, according to which "a green economy is one that results in improved human well-being and social equity, while significantly reducing environmental risks and ecological scarcities. In its simplest expression, a green economy can be thought of as one which is low carbon, resource efficient and socially inclusive. In a green economy, growth in income and employment should be driven by public and private investments that reduce carbon emissions and pollution, enhance energy, and resource efficiency, and prevent the loss of biodiversity and ecosystem services." [2]

At the same time, the green economy is seen in a broader context. The European Environment Agency (EEA) views the green economy as an integrated framework for circular economy policies (waste management, waste prevention, resource efficiency) by adding topics related to human well-being and ecosystem resilience (EEA, 2015) ${ }^{\dagger}$. In this sense, the concept of a 'green economy' covers a wider range of issues than the 'circular' and 'low-carbon' economies, the latter focusing on reducing the use of fossil fuels as a generator of climate change mitigation and prevention.

On the other hand, the OECD views the green economy as linked to research, technology and industries that are directly aimed at improving environmental performance, reducing pollution, saving energy, and protecting natural resources [3]. The concept of a green economy is linked to both the low-carbon economy and the idea of green growth. The OECD defines the concept of "green growth" as placing a strong focus on creating the necessary conditions for innovation, investment, and competitiveness to provide new sources of economic development that meet the requirements of preserving the resilience of ecosystems [4].

\section{A framework for approaches and tools for the transition to a green economy}

The article examines the research classifications used to operationalize the term green economy and possible classification of the most used measures and tools to promote its implementation. The correlation of the approaches and tools applied in Bulgaria in the processes of regional development after 2007 will help to assess the available knowledge and experience in the Bulgarian regions in support of the green economy as a tool for sustainability, given the challenges of the 2027 and 2050 goals.

The perspectives from which the green economy is considered as approaches and tools for implementation have been the subject of intensive research in the scientific community

${ }^{\dagger}$ https://www.eea.europa.eu/soer/2015/europe/green-economy 
in recent years. Although the green economy is already the focus of European and national strategy papers, researchers have widely defined the understanding of making gradual and reformist changes that do not run counter to neoliberal economic growth or consumer economies.

Various research methods have identified the dimensions and characteristics of the green economy. Bibliometric analysis, e.g., reveals the frequency of use of keywords related to the concept of "green economy" in the scientific literature after 1990 [5]. A significant share, far ahead of the next, is occupied by the "environmental dimension" (in over $25 \%$ of cases), followed by the keywords "practical implementation", "economic dimension" and "governance / institution". The next group, relevant in terms of frequency of occurrence, includes the keywords "geographical areas" and "social dimension". That is, more than half of the keywords are related to the terms environmental and economic dimension. Additional research reveals the links between key keywords and different semantic areas. The authors present interpretations of the results, according to which the green economy is often seen as a way to reduce pressure on resources, climate change and harmful emissions, while ensuring economic growth and employment. From a practical point of view, it is assumed that environmental and energy policies contribute to the support of the green economy by providing innovation and investment to achieve energy efficiency, introduction of green technologies, pollution control, bioenergy production, recycling, and circular economy activities. There is a greater connection between the "green economy" and the theory of "environmental economies" than with the theory of "environmental economies". The derived generic framework of the green economy presents biotechnologies, resource efficiency, renewable energy sources, recycling, reuse and recovery of resources as approaches for realization of "environmental economies", and as approaches for realization of "ecological economies" - the construction and use of green infrastructure (nature-based solutions), industrial symbiosis (industrial ecology \& circular economy), as well as approaches related to limiting the production and use of resources by renting products, sharing resources.

In a similar direction to the above, the review of current approaches to achieving the goals of the green economy and their relevance to various economic theories and opportunities for impact on existing environmental problems and economic growth, defines a specific categorization of approaches to green economy. A review of the different understandings of green economy approaches [1] summarizes different views [6-7], adapting them into three categories.

Table 1. Discourses of the green economy.

\begin{tabular}{|c|c|c|}
\hline \multicolumn{2}{|c|}{$\begin{array}{c}\text { Frequently articulated in policy } \leftrightarrow \text { Rarely articulated in policy } \\
\text { Incremental change } \leftrightarrow \text { Transformative change } \\
\text { Fit and conform } \leftrightarrow \text { Stretch and transform }\end{array}$} \\
\hline $\begin{array}{c}\text { Conventional pro- } \\
\text { growth/almost business as } \\
\text { usual }\end{array}$ & $\begin{array}{c}\text { Selective growth/greening the } \\
\text { economy }\end{array}$ & $\begin{array}{c}\text { Limits to } \\
\text { growth/socioeconomic } \\
\text { transformation }\end{array}$ \\
\hline $\begin{array}{c}\text { Greening as an investment } \\
\text { opportunity }\end{array}$ & Resource efficiency & $\begin{array}{c}\text { Steady-state economy } \\
\text { Prosperity without growth } \\
\text { Degrowth }\end{array}$ \\
Restarting market & Low-carbon growth & Decoupling \\
economies & Clean-technologies & Social well-being \\
Green Keynesianism & Ecological modernization & Alternative food networks \\
Green job creation & Cleantech clusters & Eco-housing developments \\
Green New Deal policies & Makerspaces & \\
\hline
\end{tabular}

Sources: Gibbs, D. and O’Neill, K. (2017) [1]

Qualitative analysis is on these three aspects, done through a study of documents, reveals that the approaches to the implementation of green economy initiatives in the studied 
strategic and planning documents of the EU (2010-2012) often belong to the group of "selective growth/greening the economy [6].

This adapted categorization is used in the following parts of the article to identify the approaches to promoting the green economy applied in the Bulgarian national strategic and planning documents after 2007.

\section{The green economy in a European context}

The Green Paper on Territorial Cohesion and the state of the debate on future cohesion policy reform [8] published in 2008 intensified the debate on issues arising from the enlargement of the EU, as well as the need to harmonize efforts to meet the challenges of the global economy and achieve sustainable economic growth.

The Europe 2020 Strategy [9] was adopted in 2010 in response to the need for a rapid and sustainable recovery from the 2008 global financial crisis. The strategy aims to transform the Union's economy into a knowledge-based, resource-efficient, and low-carbon economy, as well as to provide a sustainable response to the challenges facing the EU by 2050 . The strategy aims to integrate and strengthen the role of sustainability in development policymaking by identifying mutually supportive priorities for smart, sustainable and inclusive growth, guided by five key objectives and seven flagship initiatives, including the Resource Efficient Europe initiative [10], which aims to break the link between economic growth and resources used, to support the transition to a low-carbon economy, to increase the use of renewable energy sources, to modernize the Union's transport sector and to boost energy efficiency.

Many of the flagship initiatives of the Europe 2020 Strategy are directly related to EU Communication "Rio +20: towards the green economy and better governance" [11]. The Communication sets out the Commission's initial ideas for possible concrete results from Rio +20 and builds on a range of EU sustainable development policies and the Europe 2020 strategy.

Before the start of the new programming period, at the end of 2019, in a Communication [12], the EC presents a European Green Deal for the European Union (EU) and its citizens. The main lines of action are aimed at increasing the EU's climate ambitions for 2030 and 2050; supply of clean, accessible and secure energy; mobilizing industry for a clean and circular economy; construction and renovation in an energy and resource efficient way; accelerating the transition to sustainable and intelligent mobility; creating a fair, healthy and environmentally friendly food system; protection and restoration of ecosystems and biological diversity; achieving zero pollution to achieve a non-toxic environment. The ambition of the Green Deal also envisages ensuring the systematic inclusion of sustainable development in all EU policies, incl. mobilizing research and promoting innovation and enhancing education and training.

In March 2020, the EC reaffirmed in its working paper [13] the continuing trends for global transformation towards a circular economy, which implies a shift from linear, highly resource-depleting systems with high emissions, waste generation and strong impacts on ecosystems and natural capital to circular, -slightly wasteful systems that use resources more efficiently and sustainably, while providing job opportunities and a high quality of life.

The new Circular Economy Action Plan [14] approved at the beginning of 2021 envisages the achievement of a carbon-neutral, sustainable, toxic-free, and fully circular economy by 2050. The envisaged actions determine the transformation of the linear into a circular economy to be achieved in compliance with certain principles. The action plan, defined as central to the European Green Deal, includes action on specific topics and sectors beyond the creation of a policy framework: key product value chains; restriction of the use of certain hazardous substances in electrical and electronic equipment; review on rules on end-of-life 
vehicles and waste oils; actions in the areas of product packaging, the use of plastic products, developing an EU textile strategy, reducing waste and increasing the share of recycling. It is essential to carry out the key activities providing support for the transition to a circular economy through the Skills agenda, the forthcoming Action Plan for Social Economy, the Pact for Skills and the European Social Fund Plus, as well as through the Cohesion policy funds, the Just Transition Mechanism and urban initiatives.

In summary, in the post-2010 period, the EU has focused on reviving the Union's economy following the 2008 global financial crisis, based on the implementation of instruments protecting natural resources and reducing social inequality by launching a process to move to a low-carbon economy, increasing the energy efficiency of public and private residential and industrial buildings and facilities, promoting the use of renewable energy, modernizing public transport, investing in waste management infrastructure, protecting the air, water, agricultural land and producing clean food. The EU's ambitions for the period after 2020 are growing, and the set goals by 2050 are to achieve a modern, resource-efficient, and competitive economy, working in a fair distribution of goods and preserved natural resources.

The goals set for 2030 and 2050 are more ambitious, the approaches are more detailed, the instruments are more diverse - the ambition of the European Green Deal is for a climateneutral, resource-efficient, and circular economy. A more significant participation of business in the development of the circular economy is sought by including a wide range of economic sectors in the scope of those whose transformation will be supported [15]. It is also planned to ensure the systematic inclusion of sustainable development in all EU policies, incl. by promoting research and innovation and support in the fields of education and training.

\section{Bulgaria - approaches and tools of the green economy}

\subsection{Experience gained in the period 2007-2020}

In 2007, Bulgaria prepared its first national and regional strategic and planning documents for regional development [16-18] as an EU member. They have been developed in line with the provisions of the Union's cohesion policy strategy papers. In general, initially developed documents have a focus on the restoration of technical, economic, and social infrastructure in the Bulgarian regions, by directing investments to achieve regional growth, and priorities and measures related to the implementation of approaches and tools inherent and supporting the green economy, are provided to a very limited extent. Such measures appear in part following the 2011 updates of the strategic and planning documents [19-20]. The inclusion of the topic in the planning documents stems both from the adoption of documents at European level - "Europe 2020" Strategy and changes in national strategic documents such as the Energy Strategy of the Republic of Bulgaria until 2020 [21]. The initial version of the NSRR 2005-2015 [16] envisages measures for technological renewal of production, as well as those aimed at using the ecological potential of natural resources and promoting the processing of agricultural and forestry products to the final product, as the main instruments in support of the ecological economy. An essential element in this direction is the planning of construction and improvement of the ecological infrastructure, incl. projects for the development of renewable energy sources (hydroelectric energy, wind, solar geothermal energy, and energy generated from biomass) and energy efficiency in the public sector. Among the main mechanisms for supporting regional development is the financing of environmental projects and projects for environmentally friendly production and sustainable development under the Environmental Protection Act. 
Following the 2011 update, for the first time the NSRR 2005-2015 [19] identified the necessary support for the SME sector, oriented towards technological renewal, introduction of green technologies and production of ecological products, which in the long run will improve the market positioning of SMEs. It is planned to carry out activities aimed at introducing new technologies, incl. "Green technologies", and to the development of a knowledge-based economy. Special emphasis is placed on the support of green technologies for energy production, in accordance with the provisions of the Europe 2020 Strategy to increase by $20 \%$ the share of RES in final energy consumption; introduction of energy audits, certification and good practices for energy management in connection with the objectives of the National Long-Term Program for Energy Efficiency until 2015 [22] and "Europe 2020" to achieve energy efficiency of $20 \%$.

This approach and tools have been transferred to the implementation of the Regional Development Plans for the period 2007-2013 [17], updated in 2011 [20]. The RDPs and their updates are reviewed for three of the planning regions, covering areas which are the focus of specific measures under just transition plans developed for the period after 2021: Stara Zagora, Yambol, Sliven, Haskovo, Pernik, Kyustendil, as well as Gabrovo. All three regional development plans mainly address measures aimed at promoting renewable energy and gasification, focusing on the indisputable benefits that the introduction of RES would bring to the economic development of the regions, both by attracting investment and by protecting the environment through reduction of harmful emissions, use of biofuels in transport, technological renewal and attraction of investments in SMEs, improvement of waste management, prevention of natural risks, renewal of water supply and sewerage infrastructure.

With the new programming period in 2014, the national strategic and planning documents reflect the European goals and priorities in the field of transition to a green economy. In the strategies and plans for regional development at different levels for the period 2014-2020 $[25,26]$, the green economy "appears on the scene": the documents provide for the promotion and financing of energy efficiency measures for buildings and production facilities, use of energy from renewable sources; development of urban transport mobility; separation and processing of waste; renovation of water and sewage infrastructure.

The National Concept for Spatial Development 2013-2025 [27] considers forests as the basis of the "green" economy, due to their significant role in reducing greenhouse gas emissions into the atmosphere. The National Strategy for Regional Development 2012-2022 [25] prioritizes the development of new business models for SMEs, introduction of new technologies and innovations in SMEs; business support for technological renewal of the production sphere and development of "green" economic activities in the SME sector; the introduction of energy saving technologies and RES. In 2015, Bulgaria adopted an Innovation Strategy for Smart Specialization of the Republic of Bulgaria 2014-2020 [28]. It identifies seven technological/thematic areas for intensive innovation development/specialization. All areas are directly or indirectly related and contribute to the development of the green economy in the country. The contribution of the fields of mechatronics and clean technologies can be assessed as direct; biotechnology; pharmacy; food industry. The economic sectors within the scope of the thematic areas of specialization are financed primarily through the financial resources of the EU cohesion policy. Updated in 2017, the Innovation Strategy [29] practically "includes" the "green" guidelines implemented after 2011 at the EU level - energy efficiency technologies, waste recycling and treatment technologies, mobility and transport technologies, water supply and sewerage technologies, environmental and systems engineering, life sciences, nanotechnologies, eco-design, etc. The strategy identifies as an opportunity to participate in a relatively "large-scale" green market. The huge lag in this area has also been identified, which requires fast and high-quality absorption of technologies and knowledge to achieve a degree of integration in this market. 


\subsection{Bulgaria on the threshold of a new green challenge}

The circular economy, decarbonization, green innovations are listed in the priorities of the strategic and planning documents for the new period [30-32] - the Development Program of Bulgaria 2030, the Innovation Strategy for Smart Specialization 2021-2027, the projects of Integrated Territorial Development Strategies 2021-2027. Regional plans for financing by the Fair Transition Mechanism are under development, targeting three of the country's districts with economies dependent on coal-fired power generation - Stara Zagora, Pernik and Kyustendil. A new Innovation Strategy for Smart Specialization 2021-2027 is under development, which builds on the experience gained from the implementation of ISIS 20142020 but is programmed and will be implemented in significantly different global, European and national contexts. The thematic priority areas for smart specialization in the period 20212027, set in the strategy are five, and a separate topic is already defined for clean technologies, circular and low-carbon economy.

\section{Analysis of the results of the review}

The inclusion in the strategic and planning documents for regional development of the topics related to efficient use of resources and green economy is started in the period after 20102011 by updating already existing strategic and planning documents for regional development. This predetermines the limitation of measures and instruments with a green focus to the main ones, related to technological renewal, improvement of energy efficiency, basic ecological infrastructure. In general, there is a lack of sectoral focus on these measures. In the general case, they do not derive from specific local and regional specifics, and the instruments are applied on the territory of all planning regions and their municipalities.

In the period 2014-2020, the topic of green economy already occupies an appropriate place and is included in a wide range of planning documents for regional development, as well as in a number of national sectoral strategic documents - in the fields of energy, economy, and environmental protection. The measures in the separate sectors are aimed at rehabilitation, renewal and development of water supply and sewerage networks, waste management, production efficiency, clean air, biotechnologies. Some of the measures are justified by regional specifics. Funding for SMEs is prioritized according to the territorial scope of certain interventions.

The review of development plans in selected municipalities, for which the need for specific measures for a just transition after 2021 is justified, shows that in the periods 2007 2013 and 2014-2020 the measures related to elements of the green economy are concentrated in four main directions:

- Technological renewal of the production fund of SMEs and implementation of innovations, incl. priority after 2014 in certain thematic areas.

- Improving energy efficiency in public and residential buildings, construction of renewable energy installations, construction and expansion of gas transmission network.

- Construction of ecological infrastructure - water supply and sewerage systems, waste management systems - collection and disposal, construction of new regional landfills, prevention of natural risks.

- Protection of natural heritage and protected areas.

Although approaches to the implementation of green economy initiatives in the EU strategic and planning documents of the EU (2010-2012) often belong to the group of "selective growth / greening the economy" (Bina, 2013), this type of measures remain outside the scope of those applied in Bulgaria after 2014.

The comparison of the used measures with the above discourse and categorization of the approaches for transition to the green economy gives grounds to assess that the measures 
applied in Bulgaria for the purposes of regional development in the whole period 2007-2020 are mostly relevant to the categories «conventional growth policies inherent in ordinary business »and now partially (after 2014) to those for « selective growth »- resource efficiency, environmental modernization.

The usual instruments for "greening" as an investment opportunity are recognizable for the Bulgarian private sector thanks to their implementation and funding over the past 10 years by the Structural and Cohesion Funds. A significant share of the applied instruments (volume and finances) until 2020 are directed to the public sector through the measures for improvement of EE in public buildings, renovation of water supply and sewerage infrastructure and waste management systems, renovation, and development of public transport systems. The instruments aimed at the private sector are related to the usual business opportunities through technological renewal, which contributes to EE, and the use of RES in production.

The planning documents after 2020 envisage the application of both models and tools common to businesses and specific tools for greening the economy and aimed at resource efficiency, low-carbon growth, clean technologies, and clusters for them. During the preparation of the planning documents for regional development and the national strategic documents for the period 2021-2027, relevant to the considered topic, conclusions were made that according to the results achieved by 2020 by Bulgarian enterprises in terms of waste management are not optimal and the potential of new business models of the circular economy are not used. As a result, there is a need to raise awareness of entrepreneurs about the opportunities and benefits of developing circular business models and support for starting the production of green products and services.

\section{Conclusion and discussion questions}

The set European and national goals for the period after 2021 in the field of the circular and green economy, climate change, are ambitious. To achieve them, it is necessary to move to the application of tools for selective growth - ensuring the realization of resource efficiency, low-carbon growth, development of clean technologies and clusters for them, environmental modernization.

The implementation of the measures envisaged in the period 2021-2027 will be a challenge for the Bulgarian economy. The results of previous periods suggest the need for clarification and training of businesses to apply tools for "greening" and circular economy as part of the business model, production. The Green Deal includes measures known to the Bulgarian society, the public and the private sector, such as energy efficiency through renovation of buildings, promotion of renewable energy sources, protection of the environment and protected areas. A novelty and challenge for the public and private sector will be the operationalization of the goals for strong reduction of the generated waste and its utilization, the development of sustainable, intermodal and intelligent mobility, as well as the construction of green infrastructure for protection of natural resources. The challenges for the private sector are related to the envisages for mobilizing industry for a clean and circular economy; creating a fair, healthy and environmentally friendly food system.

Topics remain open for discussion are about the possibilities and potential for applying approaches to limiting growth, degrowth, social well-being, alternative food networks, development of eco-housing to achieve real results both for greening the economy and conserving natural resources and to increase the well-being of the population, especially in the highly depressed Bulgarian regions, such as the North-West Development Region. And if this type of approach can be seen rather as very limited to implement, then the potential for applying approaches to "greening" urban areas, public spaces and individual consumption in 
urban networks should be explored as complementary measures to these undertaken by the private sector to support the transformation to a circular and green economy.

\section{References}

1. D. Gibbs, K. O’Neill, J. RS, 51(1), 161-173 (2017)

2. UNEP, Towards a Green Economy: Pathways to Sustainable Development and Poverty Eradication - A Synthesis for Policy Makers (2011), www.unep.org/greeneconomy

3. OECD, Enabling local green growth: Addressing climate change effects on employment and local development (2012)

4. OECD, Towards Green Growth (2011) https://www.oecdilibrary.org/environment/towards-green-growth 9789264111318-en

5. E. Loiseau, L. Saikku, N. Droste, B. Hansjurgens, et al.. J. CP 139, 361-371 (2016)

6. O. Bina, EPC-GP, 31 1023-1047 (2013)

7. P. Ferguson, J. EP, 24 (1), 17-37 (2015)

8. EC, The Green Paper on Territorial Cohesion and the state of the debate on future cohesion policy reform, PM 28 (2008), https://ec.europa.eu/regional policy/en/information/publications/panoramamagazine/2008/panorama-28-green-paper-on-territorial-cohesion-the-way-ahead

9. EC, EUROPE 2020 A strategy for smart, sustainable and inclusive growth (COM/2010/2020 final), https://eur-lex.europa.eu/legalcontent/EN/ALL/?uri=celex:52010DC2020

10. EC, A resource-efficient Europe - Flagship initiative under the Europe 2020 Strategy, Brussels, 26.1.2011 COM(2011) 21, http://www.ceeweb.org/wpcontent/uploads/2012/02/resource_efficient_europe_en.pdf

11. EU Communication "Rio +20: towards the green economy and better governance" COM (2011) 363 final, https://eurlex.europa.eu/LexUriServ/LexUriServ.do?uri=COM:2011:0363:FIN:EN:PDF

12. EC, The European Green Deal, COM (2019) 640 final, https://eur-lex.europa.eu/legalcontent/EN/TXT/?uri=COM\%3A2019\%3A640\%3AFIN

13. EC, Commission staff working document Leading the way to a global circular economy: state of play and outlook SWD (2020) 100 final

14. EC, Circular Economy Action Plan (2021), https://ec.europa.eu/environment/pdf/circulareconomy/new_circular_economy action_plan.pdf

15. Regulation (EU) 2020/852 of the European Parliament and of the Council of 18 June 2020 on the establishment of a framework to facilitate sustainable investment, and amending Regulation (EU) 2019/2088 (Text with EEA relevance), https://eurlex.europa.eu/legal-content/EN/TXT/?uri=CELEX\%3A32020R0852

16. National Regional Development Strategy of the Republic of Bulgaria for the period 2005-2015 (2007), https://www.mrrb.bg/bg/national-regional-development-strategy-ofthe-republic-of-bulgaria-for-the-period-2005-2015/

17. Regional Development Plans for the period 2007-2013 (2007)

18. Municipal development plans for the periods 2007-2013 and 2014-2020, https://www.strategy.bg/StrategicDocuments/List.aspx?lang=bgBG\&categoryId=2\&typeConsultation $=2 \&$ typeCategory $=0 \&$ doc Type $=1$ 
19. Updated document for implementation of the National Strategy for Regional Development of the Republic of Bulgaria for the period 2011 - 2015 (2011), https://www.mrrb.bg/bg/aktualiziran-dokument-za-izpulnenie-na-nacionalnatastrategiya-za-regionalno-razvitie-na-republika-bulgariya-za-perioda-2011-2015-g/

20. Updated documents for implementation of the Regional Development Plans of the regions of level II (2011), https://www.mrrb.bg/bg/aktualizirani-dokumenti-zaizpulnenie-na-regionalnite-planove-za-razvitie-na-rajonite-ot-nivo-ii/

21. Energy Strategy of the Republic of Bulgaria until 2020 (2011), https://www.strategy.bg/StrategicDocuments/View.aspx?lang=bg-BG\&Id=704

22. National Long-Term Program for Energy Efficiency until 2015 (2005), https://www.me.government.bg/bg/library/nacionalna-dalgosrochna-programa-poenergiina-efektivnost-do-2015-g-184-c174-m1-1.html

23. National Action Plan for Renewable Energy (2013), https://www.strategy.bg/StrategicDocuments/View.aspx?lang=bg-BG\&Id=781

24. National Program for Energy Efficiency of Multifamily Residential Buildings https://www.mrrb.bg/bg/energijna-efektivnost/nacionalna-programa-za-ee-namnogofamilni-jilistni-sgradi/

25. National Regional Development Strategy of the Republic of Bulgaria 2012-2022, (2012) https://www.mrrb.bg/bg/national-regional-development-strategy-of-therepublic-of-bulgaria-2012-2022/

26. Regional development plans for the regions of level 2 for the period 2014-2020 (2014), https://www.mrrb.bg/bg/regionalni-planove-za-razvitie-na-rajonite-ot-nivo-2-zaperioda-2014-2020-g-prieti-s-reshenie-na-ms/

27. National Concept for Spatial Development 2013-2025 (2014), https://www.mrrb.bg/bg/nacionalna-koncepciya-za-prostranstveno-razvitie-za-perioda2013-2025-godina/

28. Innovation Strategy for Smart Specialization of the Republic of Bulgaria 2014-2020, https://strategy.bg/StrategicDocuments/View.aspx?lang=bg-BG\&Id=975

29. Updated Innovation Strategy for Smart Specialization of the Republic of Bulgaria 2014-2020 (2017), https://strategy.bg/StrategicDocuments/View.aspx?lang=bgBG\&Id=975

30. National Development Program BULGARIA 2030, https://www.minfin.bg/bg/1394

31. Update of the National Concept for Spatial Development for the period $2013-2025$ (2020), https://www.mrrb.bg/bg/aktualizaciya-na-nacionalnata-koncepciya-zaprostranstveno-razvitie-za-perioda-2013-2025-g/

32. Drafts of the Integrated Territorial Strategies for Development of the Level 2 Planning Regions for the period 2021-2027 (2020), http://www.bgregio.eu/programirane-iotsenka/proektite-na-regionalni-shemi-za-prostranstveno-razvitie-sa-publikuvani-zaobshtestveno-obsazhdane.aspx 